\title{
Effect of Substituting Corn with Cobs Treated with Combinations of Urea and Wood Ash on Chemical Composition and Invitro Gas Production Substrate
}

\author{
Abdulrazaq ABDULAZEEZ ${ }^{1}$, Othusitse Ricky MADİBELA ${ }^{2}$, Christopher Mareledi \\ TSOPITO $^{2}$
}

\author{
${ }^{1}$ Federal College of Education (Technical) Gusau, Zamfara State, Nigeria. \\ ${ }^{2}$ Department of Animal Science, Faculty of Animal and Veterinary Sciences, \\ Botswana University of Agriculture and Natural Resources, Gaborone, Botswana
}

Abdulrazaq ABDULAZEEZ, ORCID No:0000-0001-5627-6135, Othusitse Ricky MADİBELA, ORCID No:0000-0003-0450-3505, Christopher Mareledi TSOPITO, ORCID No:0000-0003-1965-164X

\begin{tabular}{|c|c|}
\hline ARTICLE INFO & ABSTRACT \\
\hline $\begin{array}{l}\text { Research Article } \\
\text { Summarised from PhD thesis and } \\
\text { also presented at the } 11^{\text {th }} \\
\text { International Animal Science } \\
\text { Conference, Cappadocia,Turkey. } \\
\text { Received : } 12.04 .2021 \\
\text { Accepted : } 11.06 .2021\end{array}$ & $\begin{array}{l}\text { This trial was aimed at determining the effect of substituting corn with } \\
\text { cobs treated with urea }(25 \%) \text { and wood ash }(75 \%) \text { on chemical } \\
\text { composition and gas production substrate. Corn was substituted with } \\
\text { graded levels of treated cobs in the dietary ingredients and the } \\
\text { treatments were: } 100 \mathrm{M}=100 \% \text { corn, } 66 \mathrm{M} 34 \mathrm{C}=66 \% \text { corn with } 34 \% \\
\text { treated cobs, } 34 \mathrm{M} 66 \mathrm{C}=34 \% \text { corn with } 66 \% \text { treated cobs and } 100 \mathrm{C}= \\
100 \% \text { treated cobs. Samples were analyzed for dry matter (DM), organic } \\
\text { matter (OM), ash, crude protein (CP), neutral detergent fibre (NDF), } \\
\text { acid detergent fibre (ADF) and acid detergent lignin (ADL); they were } \\
\text { then incubated in vitro for } 6,12,24,48 \text { and } 72 \text { hrs. Results indicated } \\
\text { that as corn is substituted with treated cobs, NDF, ADF and ADL also } \\
\text { increased, however only the NDS for treatment } 100 \mathrm{C} \text { was reduced. The } \\
\text { result of the truly degraded substrate (TDS) parameters also indicated } \\
\text { that treatment } 34 \mathrm{M} 66 \mathrm{C} \text { had the highest TDS, gas production (GP), } \\
\text { microbial mass production (MMP), efficiency of microbial mass } \\
\text { production (EMMP) and partitioning factor (PF). In conclusion, } 66 \% \text { of } \\
\text { treated cobs could replace corn in a complete diet without effects on } \\
\text { measured parameters. }\end{array}$ \\
\hline
\end{tabular}

\section{Üre ve Odun Külü Kombinasyonları ile İşlenmiş Koçanların Mısır ile İkamesinin Kimyasal Bileşim ve Gaz Üretim Substratı Üzerindeki Etkisi}

\section{MAKALE B İ LGİS İ}

\section{Araştırma Makalesi}

Doktora tezinden özetlenmiş ve 11 . Uluslararası Zootekni Konferansnda sunulmuştur, Kapadokya, Türkiye.

\section{ÖZET}

Lütfen aşağıdaki şekilde atıf yapınız / Pleasecitethispaper as following;

Abdulazeez, A., Madibela, O.R., Tsopito, C.M., 2021. Effect of substituting corn with cobs treated with combinations of urea and wood ash on chemical composition and invitro gas production substrate, Journal of Animal Science and Products (JASP)

4 (1):85-95. DOI: 10.51970/jasp.914984 
Geliș: 12.04.2021

Kabul: 11.06.2021

\section{Anahtar Kelimeler}

Gerçek sindirilebilirlik,

Mikrobiyal kütle proteini,

parçalanma faktörü,

Mahsul kalıntısı

* Sorumlu Yazar

azeezrazaq70@gmail.com koçan ve 100C =\% 100 muamele edilmiş koçan. Örnekler, kuru madde $(\mathrm{KM})$, organik madde (OM), kül, ham protein (HP), nötral deterjan selüloz (NDF), asit deterjan selüloz (ADF) ve asit deterjan lignin (ADL) bakımından analiz edilmiş; daha sonra in vitro olarak 6, 12, 24, 48 ve 72 saat inkübe edilmiştir. Sonuçlar, mısırın muamele edilmiş koçanlarla ikame edildiğinde, NDF, ADF ve ADL düzeyinin arttığını, ancak sadece 100C muamele grubunda NDS'nin azaldığını göstermiştir. Gerçek sindirilebilirlik (GS) parametreleri sonuçları, 34M66C muamelesinin en yüksek GS'ye, gaz üretimine (GP), mikrobiyal kütle üretime (MKÜ), mikrobiyal kütle üretim verimliliğine (EMMP) ve parçalanma faktörüne (PF) sahip olduğunu göstermiştir. Çalışmada elde edilen sonuçlar, işlenmiş koçanların ölçülen parametreler üzerinde herhangi bir etki olmaksızın rasyonda mısırın \% 66'sı yerine kullanılabileceğini ortaya koymuştur.

\section{Introduction}

Wood ash derived from fire wood is alkaline and had been used to improve the digestibility of crop residues the same way as urea and is available at household level at no cost to the farmer. Some researchers (Sundstol,1985; Preston, 1985; Chenost, 1995; and Fall et al., 1989)) based their work on urea while others ( Adebowale et al.1991; Ramirez et al., 1991; Nolte et al., 1987); and Solomon et al., 2012) on wood ash for crop residue treatments and not combinations of the two. The combination is expected to reduce cost of treatment, improve digestibility at the same time incorporating both nitrogen and minerals into the crop residue.

After corn harvest and shelling of the grains, the cobs are left in the homestead as waste and in some cases are burnt. Meanwhile, livestock compete with humans for grain, therefore there is need to conserve grains for human consumption by either partially or completely replacing it with treated cobs which are rich in energy, nitrogen and minerals.

Feed quality characterization and predictions of intake, digestibility and performance were mostly from in vitro gas production parameters only as reported by Menke \&Steingass, (1988)., Blummel \&Orskov, (1993) and Khazaal et al. (1993) which may be misleading and unreliable (Makkar, 2010). Therefore, feed quality characterization and predictions of intake, digestibility and performance from in vitro gas production in conjunction with its truly degraded substrate parameters - truly degraded substrate (TDS), gas production (GP), microbial mass production(MMP), efficiency of microbial mass production (EMMP) and partioning factor (PF)- would give a more reliable result. This study aimed at investigating the effect of substituting corn with cobs treated with urea and wood ash on chemical composition and gas production substrate.

\section{Material and Methods}

The study was carried out at Botswana University of Agriculture and Natural Resources, Gaborone, Botswana. Corn cobs treated with a combination of $25 \%$ urea and $75 \%$ 
wood ash described in a previous study were used to substitute graded level of corn in a complete diet (Table 1)

\section{Sample Analysis}

Dry matter for all samples were determined by drying in forced air oven at $60^{\circ} \mathrm{C}$ for $24 \mathrm{hr}$ (DM, ID number 930.15) while OM (OM, ID number 942.05) and ash were obtained by difference in weight after ignition at $550^{\circ} \mathrm{C}$ in a muffle furnace (Muffle Furnace Size 3, Gallenkamp, UK). ANKOM fiber analyzer was used to determine NDF, ADF and ADL (Ankom Technology Corporation, Fairport, NY, USA) according to the procedure of Van Soest et al, (1991). Sodium sulphite and alpha amylase were also added in the analysis of NDF. Nitrogen was determined by the Kjeldahl method according to AOAC (1999) (ID number 955.04) while $\mathrm{CP}$ was determined by multiplying $\mathrm{N}$ by 6.25 (ID number 954.01).

\section{In vitro Gas Production}

Prior to incubation of feed samples in calibrated glass syringes with rumen fluid, they were milled using $1 \mathrm{~mm}$ sieve (Menke \& Steingass, 1988). The rumen fluid was obtained from two fistulated steers fed commercial concentrate mixed with crushed corn cobs. After collection of the rumen liquor in a thermo flask, it was then flushed with carbon dioxide in order to create an anaerobic conditions needed by rumen microorganisms. Samples (500mg) were weighed in triplicates into calibrated glass syringes of $100 \mathrm{ml}$ and then pre warmed at $39^{\circ} \mathrm{C}$ followed by injection of $30 \mathrm{ml}$ rumen fluid-buffer $(2: 1 \mathrm{v} / \mathrm{v})$ mixture into each syringe. The introduction of the rumen fluid into the syringe was done with $\mathrm{CO}_{2}$ flushing followed by incubation in a water bath at $39^{\circ} \mathrm{C}$. The buffer used was made up of:

(1) $\mathrm{MgSO}_{4} \cdot \mathrm{H}_{2} \mathrm{O}+\mathrm{NaCl}+\mathrm{KH}_{2} \mathrm{SO}_{4}+\mathrm{CaCl}_{2} \cdot \mathrm{H}_{2} \mathrm{O}+$ Urea

(2) $\mathrm{NaSO}_{4} \cdot 9 \mathrm{H}_{2} \mathrm{O}+\mathrm{NaCO}_{3}$.

The gases produced were then recorded at intervals of 6, 12, 24, 48 and 72 hours. The processes were repeated three times and means for each run was used as a replicate.

In the determination of TDS, the procedure outlined by Makkar, (2010) was followed. The residues left after 72 hours incubation in the glass syringes were treated with NDF solution in a beaker for one hour. The residues were then filtered into a crucible, washed with hot water and oven dried overnight at $100^{\circ} \mathrm{C}$. In order to determine weight of undegraded feed sample, the weight of empty crucibles were subtracted from the weight of crucibles plus undegraded feed residues. The undegraded samples were then transferred to the muffle furnace and ashed at $550^{\circ} \mathrm{C}$. In vitro truly TDS parameters were then determined according to the procedure outlined by Makkar, (2010) as follows:

$\begin{array}{ll}\text { Weight of undegraded residue } & =\mathrm{a}(\mathrm{mg}) \\ \text { Weight of ash } & =\mathrm{b}(\mathrm{mg}) \\ \text { Truly undegraded organic matter } & =\mathrm{a}-\mathrm{b} \\ (500 * \mathrm{DM} \% / 100)(1-\mathrm{ash} \% / 100) & =\mathrm{c}(\mathrm{mg}) \\ \% \text { organic matter digestibility } & =(\mathrm{a}-\mathrm{b}) 100 / \mathrm{c} \\ \text { Microbial mass production }(\mathrm{mg}) & =(\mathrm{a}-\mathrm{b})-2.2 \mathrm{GP}_{24 \mathrm{hr}} \\ \text { Efficiency of microbial mass production } & =\left((\mathrm{a}-\mathrm{b})-2.2 \mathrm{GP}_{24 \mathrm{hr}}\right) / \mathrm{a}-\mathrm{b}\end{array}$




$$
\begin{aligned}
& \text { Partitioning factor } \\
& \mathrm{ME}(\mathrm{MJ} / \mathrm{Kg} \mathrm{DM})
\end{aligned}
$$$$
2.2
$$$$
\mathrm{GP}_{24 \mathrm{hr}}
$$

$$
\begin{aligned}
& =\mathrm{c}-(\mathrm{a}-\mathrm{b}) / \mathrm{GP}_{24 \mathrm{hr}} \\
& =2.20+0.136 \mathrm{GP}_{24 \mathrm{hr}} \quad+0.057 \mathrm{CP} \\
& =\text { Stoichiometric factor } \\
& =\text { Gas production at } 24 \text { hours }
\end{aligned}
$$

\section{Statistical Analysis}

Chemical composition and TDS were analyzed using the general linear models (GLM) procedure of SAS (2002), while in vitro gas production constants were generated with Non Linear Model (NLIN) SAS programme using the code of Osuji et al. (1993). GLM procedure of SAS (2002) was used to determine treatment effects and means were separated with Duncan's multiple range test (Steel and Torrie, 1984). Excel was then used to plot the line graph for the gas production profile.

The model used in the statistical analysis was:

$\mathrm{Y}_{\mathrm{i}}=\mu+\mathrm{T}_{\mathrm{i}}+\mathrm{e}_{\mathrm{i}}$

where:

$\mathrm{Y}_{\mathrm{i}}=$ measured parameters,

$\mu=$ general mean

$\mathrm{T}_{\mathrm{i}}=$ types of treatment $(1-4)$,

$\mathrm{e}_{\mathrm{i}}=$ residual error

\section{Determination of gas production parameters}

In order to determine the gas production parameters, cumulative gas production was fitted into the exponential equation of Orskov \& McDonald (1979), $\mathbf{P}=\mathbf{a}+\mathbf{b}\left(\mathbf{1}-\mathbf{e}^{\text {-ct }}\right)$

where:

$\mathrm{P}=$ Gas production at time $\mathrm{t}$

$\mathrm{a}=$ Gas production from the immediate soluble fraction $(\mathrm{ml})$,

$\mathrm{b}=$ Gas production from the insoluble fraction $(\mathrm{ml})$,

c $=$ Gas production rate constant.

$\mathrm{a}+\mathrm{b}=$ Potential gas production $(\mathrm{ml})$

ed $=$ effective gas production

$\mathrm{t}=$ Time of incubation (hr). 


\section{Results}

Table 1. Ingredients and chemical composition $(\mathrm{g} / \mathrm{kg})$ of experimental diets Tablo 1. Diyetlerin bileşenleri ve kimyasal bileşimleri $(\mathrm{g} / \mathrm{kg}$ )

\begin{tabular}{llllll}
\hline \multicolumn{5}{c}{ Treatments } \\
\hline Components (\%) & $100 \mathrm{M}$ & $66 \mathrm{M} 34 \mathrm{C}$ & $34 \mathrm{M} 66 \mathrm{C}$ & $100 \mathrm{C}$ & \\
\hline Treated cobs & 0.00 & 15.0 & 30.0 & 45.0 & \\
Corn & 45.0 & 30.0 & 15.0 & 0.00 & \\
Lucerne & 39.0 & 36.0 & 32.5 & 29.5 & \\
Wheat bran & 10.0 & 10.0 & 10.0 & 10.0 & \\
Sun Flower Cake & 5.00 & 8.00 & 11.5 & 14.5 & \\
Salt & 0.50 & 0.50 & 0.50 & 0.50 & \\
DCP & 0.50 & 0.50 & 0.50 & 0.50 & \\
Chemical composition $(\mathrm{g} / \mathrm{kg})$ & & & & $\mathrm{SD} \pm$ \\
DM & 945.0 & 950.0 & 950.0 & 955.0 & 4.630 \\
ASH & 82.01 & 100.0 & 107.9 & 175.4 & 38.68 \\
OM & 918.0 & 900.0 & 892.1 & 824.6 & 38.68 \\
CP & 134.3 & 131.0 & 133.5 & 133.5 & 3.740 \\
NDF & 470.0 & 470.0 & 480.0 & 570.0 & 54.97 \\
ADF & 160.0 & 220.0 & 250.0 & 360.0 & 78.51 \\
ADL & 53.20 & 63.20 & 85.20 & 114.4 & 28.61 \\
HC & 310.0 & 250.0 & 230.0 & 210.0 & 53.45 \\
NDS & 530.0 & 530.0 & 520.0 & 430.0 & 54.97 \\
ME MJ/kg & 19.00 & 19.20 & 19.28 & 17.24 & 0.938 \\
\hline
\end{tabular}

$\mathrm{DM}=$ Dry matter, $\mathrm{OM}=$ organic matter, $\mathrm{CP}=$ crude protein. $\mathrm{NDF}=$ neutral detergent fibre, $\mathrm{ADF}=$ acid detergent fibre, $\mathrm{ADL}=$ acid detergent lignin, $\mathrm{HC}=$ hemicellulose, $\mathrm{NDS}=$ neutral detergent soluble, $\mathrm{ME}=$ metabolizable energy, $\mathrm{DCP}=$ dicalcium phosphate.

Table 1 shows the ingredients and chemical composition of experimental diets. It was observed that the NDF, ADF and ADL of the experimental diets increased as corn was substituted with treated cobs; however, treatment 100C had the lowest NDS.

Figure 1 shows the in vitro gas production characteristics of experimental diets. Effect $(\mathrm{P}=0.0013)$ of treatments was observed at $12 \mathrm{hrs}$ of incubation. Treatments $100 \mathrm{M}, 66 \mathrm{M} 34 \mathrm{C}$ and 34M66C had similar gas production $(41.5,41.5$ and $40.0 \mathrm{ml})$ while treatment $100 \mathrm{C}$ had the least gas production $(30.00 \mathrm{ml})$. Effect $(\mathrm{P}<0.0001)$ of treatment was also observed at 72 hrs of incubation with treatment $100 \mathrm{C}$ having the highest gas production $(52.00 \mathrm{ml})$ followed by $34 \mathrm{M} 66 \mathrm{C}(51.00 \mathrm{ml})$. Treatments $100 \mathrm{M}$ and $66 \mathrm{M} 34 \mathrm{C}$ had similar gas production $(50.00$ $\mathrm{ml})$. 


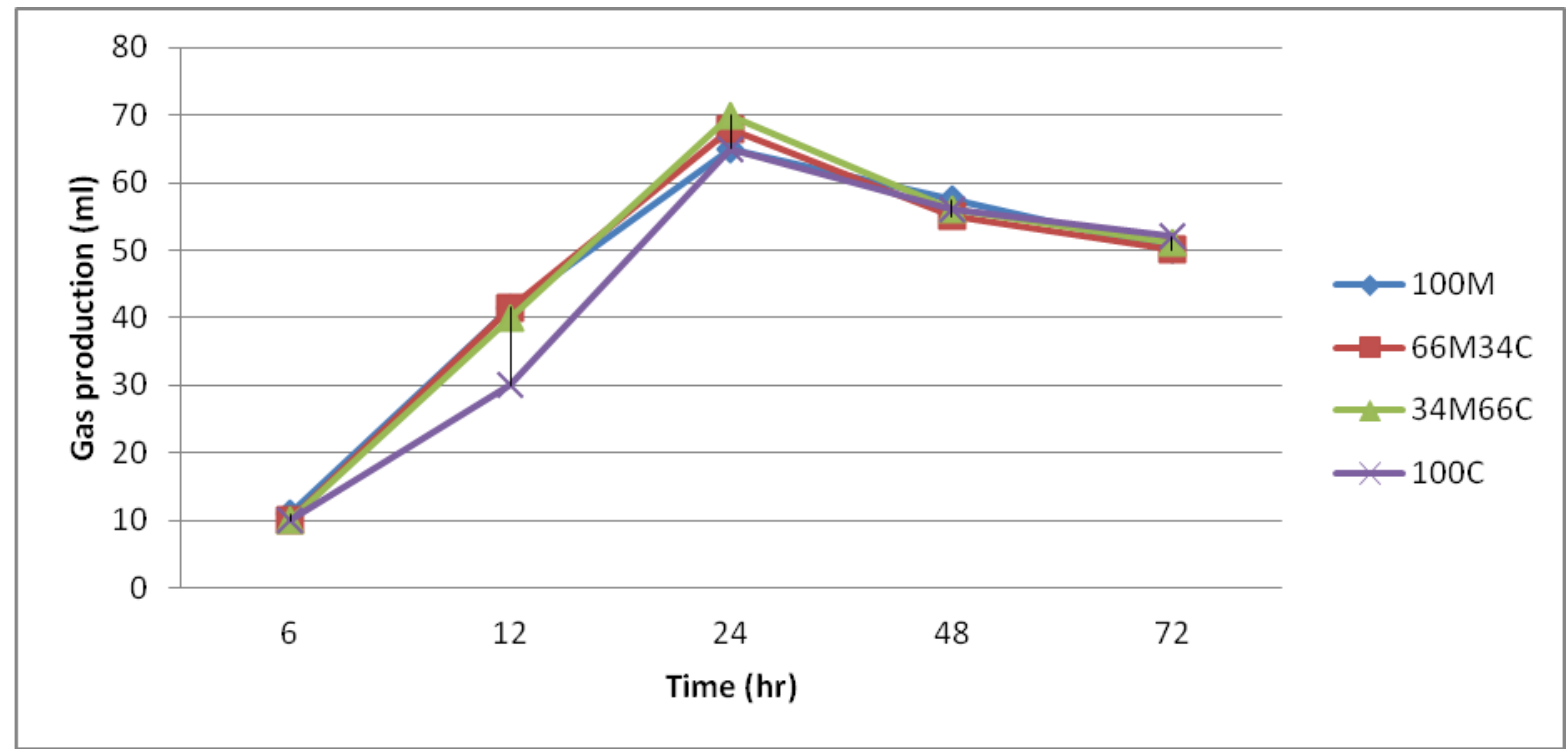

Figure 1: In vitro gas production characteristics of experimental diets

Şekil 1: Diyetlerin in vitro gaz üretim karakteristikleri

Table 2 shows the in vitro gas production parameters $(\mathrm{a}=$ gas production from the immediate soluble fraction $(\mathrm{ml}), \mathrm{b}=$ gas production from the insoluble fraction $(\mathrm{ml}), \mathrm{c}=$ gas production rate constant. $\mathrm{a}+\mathrm{b}=$ Potential gas production $(\mathrm{ml})$, ed = effective gas production) of experimental diets. Effect $(\mathrm{P}=0.0054)$ of treatments was only observed on effective gas production 'ed' while the rest of the parameters were similar. Treatment 100C had the least 'ed' $(36.91 \mathrm{ml})$ while gas production 'ed' for the rest of the treatments was similar (43.14, 43.77 and $44.17 \mathrm{ml})$.

Table 2. In vitro gas production (ml) parameters of experimental diets

Tablo 2. Diyetlerin in vitro gaz üretimi $(\mathrm{ml})$ parametreleri

\begin{tabular}{lllllll}
\hline & \multicolumn{7}{c}{ Treatments } \\
\hline Parameters & $100 \mathrm{M}$ & $66 \mathrm{M} 34 \mathrm{C}$ & $34 \mathrm{M} 66 \mathrm{C}$ & $100 \mathrm{C}$ & SE & P value \\
\hline $\mathrm{a}$ & -2.613 & -2.908 & -2.680 & -4.471 & 0.4441 & 0.4928 \\
$\mathrm{~b}$ & 61.85 & 61.86 & 61.86 & 62.11 & 0.0700 & 0.6033 \\
$\mathrm{c}$ & 0.0853 & 0.0923 & 0.0942 & 0.0780 & 0.0030 & 0.2069 \\
$\mathrm{a}+\mathrm{b}$ & 59.23 & 58.95 & 59.17 & 57.64 & 0.4309 & 0.6230 \\
$\mathrm{ed}$ & $43.14^{\mathrm{a}}$ & $43.77^{\mathrm{a}}$ & $44.17^{\mathrm{a}}$ & $40.39^{\mathrm{b}}$ & 0.5743 & 0.0054 \\
\hline
\end{tabular}

$\mathrm{a}=$ gas production from soluble fraction, $\mathrm{b}=$ insoluble but fermentable gas production from insoluble but fermentable fraction, $c=$ gas production rate, $a+b=$ potential gas production, $\mathrm{ed}=$ effective gas production.

Truly degraded substrate (mg), GP (ml), MMP (mg), EMMP and PF of experimental diets are shown in Table 3. There was effect $(\mathrm{P}<0.0001)$ of treatments on TDS $(\mathrm{mg})$. Treatments 100M, 66M34C and 34M66C had similar TDS (mg) (353.7, 352.5 and $363.7 \mathrm{mg}$ respectively) while treatment $100 \mathrm{C}$ recorded the least $(288.7 \mathrm{mg})$. Effect $(\mathrm{P}<0.0001)$ of treatment was observed on TDS $(\%)$. There was effect $(\mathrm{P}<0.0001)$ of treatment on GP at 24 hours of incubation. Treatment $100 \mathrm{C}$ had the lowest gas production $(105.0 \mathrm{ml})$ while treatment $36 \mathrm{M} 64 \mathrm{C}$ had the highest $(120.0 \mathrm{ml})$ but similar to those of treatments $100 \mathrm{C}$ and 
66M34C $(117.5$ and $119.5 \mathrm{ml})$. Effect $(\mathrm{P}<0.0001)$ of treatment was observed on MMP. Treatment 34M66C had the highest MMP $(99.75 \mathrm{mg})$ but similar to those of treatments 100C and 66M34C (95.25 and $89.60 \mathrm{mg})$ while treatment $100 \mathrm{C}$ had the least $(57.75 \mathrm{mg})$. Effect (P $<0.001$ ) of treatment was also observed on EMMP and followed the same trend as in MMP. Treatment 34M66C had the highest efficiency (27.42) but similar to those of treatments 100C and 34M64C (26.91 and 25.40) while treatment 100C had the least efficiency (19.96). Effect $(\mathrm{P}<0.0001)$ of treatments was observed on PF. Treatment 34M66C had the highest PF (3.301) and similar to those of treatments 100C and 34M66C (3.012 and 2.949). Treatment 100C also had the least PF (2.749).

Table 3. In vitro TDS parameters of experimental diets

Tablo 3. Diyetlerin in vitro TDS parametreleri

\begin{tabular}{lllllll}
\hline \multicolumn{5}{c}{ Treatments } \\
\hline Parameters & $100 \mathrm{M}$ & $66 \mathrm{M} 34 \mathrm{C}$ & $34 \mathrm{M} 66 \mathrm{C}$ & $100 \mathrm{C}$ & SE & P value \\
\hline TDS (mg) & $353.700^{\mathrm{a}}$ & $352.500^{\mathrm{a}}$ & $363.700^{\mathrm{a}}$ & $288.700^{\mathrm{b}}$ & 7.8420 & $<0.0001$ \\
GP (ml) & $117.500^{\mathrm{a}}$ & $119.500^{\mathrm{a}}$ & $120.000^{\mathrm{a}}$ & $105.000^{\mathrm{b}}$ & 1.6630 & $<0.0001$ \\
MMP (mg) & $95.250^{\mathrm{ab}}$ & $89.600^{\mathrm{b}}$ & $99.750^{\mathrm{a}}$ & $57.750^{\mathrm{c}}$ & 4.4130 & $<0.0001$ \\
EMMP & $26.910^{\mathrm{ab}}$ & $25.400^{\mathrm{b}}$ & $27.420^{\mathrm{a}}$ & $19.960^{\mathrm{c}}$ & 0.8126 & $<0.0001$ \\
PF & $3.012^{\mathrm{ab}}$ & $2.949^{\mathrm{b}}$ & $3.031^{\mathrm{a}}$ & $2.749^{\mathrm{c}}$ & 0.0309 & $<0.0001$ \\
\hline
\end{tabular}

TDS=Truly degraded substrate, $\mathrm{GP}=$ gas production, $\mathrm{MMP}=$ microbial mass production, EMMP $=$ efficiency of microbial mass production and $\mathrm{PF}=$ partioning factor

\section{Discussion}

In a previous study, corn cobs treated with urea (25\%) combined with wood ash (75\%) led to reduction in NDF, ADF and improvement in NDS, TDS and the PF compared to the rest of the treatments. Based on the results, corn cobs treated with urea $(25 \%)$ combined with wood ash (75\%) was used in a graded level to replace corn in a complete diet.

It was observed that the more the substitutions of corn with treated maize cobs, the higher the ash contents of the feed. The high amount of ash in the feed may supply more minerals to the animals and rumen microbes (Nolte et al.,1987; Ramirez et al.,1991; Imbeah, 1999;). However, the substitution also led to increase in NDF, ADF and ADL and reduction in NDS of treatment $100 \mathrm{C}$. The higher NDS content of treatments $100 \mathrm{M}, 66 \mathrm{M} 34 \mathrm{C}$ and $34 \mathrm{M} 66 \mathrm{C}$ could be attributed to their corn contents that were mostly cell soluble compared to treatment $100 \mathrm{C}$ that was characterized by higher contents of NDF, ADF and ADL which can negatively affect digestibility. Various authors have also reported increases in NDF, ADF and ADL when energy source is substituted with corn cobs (Khan et al., 2006; Wanapat et al., 2012). The reason for the high NDF and ADF contents of treatment $100 \mathrm{C}$ could be attributed its high crude fibre content.

Treatment 100C had the highest gas production at 72 hours of incubation however, gas production alone cannot be used to characterize quality of feed since gases from bicarbonate buffer may also contribute to the gas production which may be misleading (Blummel et al., 2005; Makkar, 2010). Gas production alone may also imply fermented waste products from microbial lyses to VFAs and gases including methane that pollutes the environment (Blummel and Orskov, 1993). In order to overcome these problems associated with gas production 
technique, concomitant determination of TDS of incubated substrate is therefore necessary for a reliable result.

Treatment $100 \mathrm{C}$ had the lowest effective gas production and effective degradability probably due to its high NDF, ADF and ADL contents which are known to negatively affect digestibility of fibre. The low NDS contents of treatment 100C might have also led to its low effective degradability since rumen microbes make use of cell soluble for their growth and multiplication, which invariably impacts on colonization and attachment that result in degradability of fibre (Allen and Mertens, 1988).

The fact that treatment 34M66C had the highest percent TDS even though not statistically different from those of $100 \mathrm{M}$ and $66 \mathrm{M} 34 \mathrm{C}$, may imply that it was more digestible compared to the other treatments. This may be attributed to its low grain contents that were favorable to the rumen microbes. Higher contents of dietary grain are rapidly fermented leading to low ruminal $\mathrm{pH}$ which inactivate cellulolytic bacteria that digest fibre with a resultant effect of low DM intake. This problem can be addressed by reducing the amount of grain in diets in order to promote the activities of cellulolytic bacteria that degrade fibre to reduce rumen fill and promote voluntary feed intake (Allen and Oba, 1996).

Even though treatment 100M had similar TDS (mg), GP, MMP, EMMP and PF with $66 \mathrm{M} 34 \mathrm{C}$ and $34 \mathrm{M} 66 \mathrm{C}$, its higher grain contents may have a negative impact on voluntary dry matter intake (DMI) since high grain contents lead to low $\mathrm{pH}$ and digestibility. Oba and Allen (2000) reported that when forages that are more fermentable were fed, rumen $\mathrm{pH}$ could be lowered leading to low NDF digestibility. In the same manner when rapidly fermentable grains were fed, ruminal $\mathrm{pH}$ is lowered leading to lower NDF digestibility, however, ruminal starch digestibility is increased (Overton et al., 1995). Apart from impediment to fibre digestion as a result of inactivity of fibre digesting rumen microbes due to low $\mathrm{pH}$ associated with fed grains, cases of acidosis are also common. The implication of low rumen $\mathrm{pH}$ as a result of starch digestion is that protein digestion may also be affected. Therefore, inclusion of other sources of fibre such as maize cobs in the diet could normalize the rumen $\mathrm{pH}$ thereby curbing incidence of acidosis.

It also implies use of more grains which create competition between humans and ruminants for food and feed. The advantage of treatment 34M64C, however, is that it may produce better results than the rest of the treatments when fed to ruminants due to its low corn content. The treatment will also reduce cost of feed since corn cobs are almost available freely. Another advantage associated with treatment 34M66C is that, it has high ash content which is also a valuable source of minerals to the animals and rumen microbes (Nolte et al.,1987; Ramirez et al.,1991; Imbeah, 1999). Feed with higher PF implied that the degraded organic matter may be incorporated into microbial mass that would be digested postruminally which is an indication that it has higher efficiency of microbial synthesis. Many authors have reported that feeds with higher values of PF have higher excretion of purine derivatives, higher DMI and lower methane production (Blummel et al., 2005; Makkar, 2010). It therefore implies that treatment 34M66C would translate to excretion of more purine derivatives, more DMI and lower methane emission as compared to the other treatments. 


\section{Conclusion}

It was established from all parameters considered that treatment 34M66C gave a better result compared to the other treatments. It was therefore concluded that $66 \%$ of treated corn cobs could be used in conjunction with $34 \%$ of corn in ruminants' diets.

\section{Acknowledgement}

This research work was sponsored by Tertiary Education Trust Fund (TETFUND) Abuja, Nigeria and it is hereby acknowledged.

\section{References}

Adebowale, E.A., Orskov, E.R. and Shand, W. J., 1991. Use of ash of cocoa pod husk as source of alkali for upgrading agricultural residues with or without hydrogen peroxide. Tropical Agriculture. 68: 27-32.

Allen, M. S., Mertens, D.R., 1988. Evaluating constraints on fiber digestion by rumen microbes. Journal of . Nutrition. 118: 216-270.

Allen, M. S. and Oba, M., 1996. Fiber digestibility of forages. Proc. 57th Minnesota Nutrition Conf., Univ. of Minnesota, St. Paul, MN.

AOAC, 1999. Official Methods of Analysis, $16^{\text {th }}$ ed. Official Methods of Analysis of AOAC International, Gaithersburg, MD, USA.

Blummel, M. and Orskov, E.R., 1993. Comparison of in vitro gas production and nylon bag degradability of roughages in predicting of food intake in cattle. Animal Feed Science Technology. 40: 109-119.

Blummel, M., Givens, D.I. and Moss, A.R., 2005. Comparison of methane produced by straw fed sheep in open - circuit respiration with methane predicted by fermentation characteristics measured by an in vitro gas procedure. Animal Feed Science Technology. 123-124: 379 - 390.

Chenost, M., 1995. Optimizing the Use of Poor Quality Roughage through Treatments and Supplementation in Warm Climate Countries with Particular Emphasis on Urea Treatment. First Electronic Conference on Tropical Feeds with Particular Emphasis on Urea Treatment FAO, Rome.

Fall, S., Guerin, H., Sall, C. and Mbaye, N.D., 1989. Cereal straws in the feeding system of ruminant in Senegal. Overcoming constraints to the efficient utilization of agricultural byproducts as animal feed In: (Eds. Adegabola, A. A., J.A. Kategile., D.A. Little,). Proceedings of the Fourth Annual Workshop Held at the Institute of Animal Research Mankon Station African Research Network for Agricultural Byproducts (ARNAB), Addis Ababa, Ethiopia.

Imbeah, M., 1999. Wood ash as mineral supplement for growing lambs under village conditions in the tropics Small Ruminant Research. 32: 191-194.

Khan, M.A., Iqbal, Z., Sarwar, M., Nisa, M., Lee, M. S., Khan, W.S. and Kim, H.S., 2006. Urea treated maize cobs ensiled with or without additives for buffaloes: Ruminal 
characteristics, digestibility and nitrogen metabolism Asian-Australian Journal of Animal Science. 5: 705- 712.

Khazaal, K., Denthino, M.T., Robeiro, J. M. and Orskov, E.R., 1993. A comparison of gas production during incubation with rumen contents in vitro and nylon bag degradability as predictors of apparent digestibility in vivo and the voluntary intake of hays. Animal Production. 57:105-112.

Makkar, H.P., 2010. In Vitro Screening of Feed Resources for Efficiency of Microbial Protein Synthesis. In: (Eds. Vercoe, P., H.P. Makkar., A. Schlink,) In vitro screening of plant resources for extra-nutritional attributes in ruminants: nuclear and related methodologies. Springer, Dordrecht.

Menke, K.H. and Steingass, H., 1988. Estimation of the energetic feed value obtained from chemical analysis and in vitro gas production using rumen fluid. Anim. Res. Dev. 28: 7-55.

Nolte, M.E., Cline, J.H., Dehority, B.A., Loerch, S.C. and Parker, C.F., 1987. Treatment of wheat straw with alkaline solutions prepared from wood ashes to improve fibre utilization by ruminant. Journal of Animal Science 64: 669-677.

Oba, M., Allen, M.S., 2000. Effects of brown midrib mutation in corn silage on productivity of dairy cows fed two concentrations of dietary neutral detergent fiber: Digestibility and microbial efficiency. Journal of Dairy Science 83:1350-1358.

Orskov, E.R., McDonald, L.M., 1979. The estimation of protein degradability in the rumen from incubation measurement weighted according to rate of passage. Journal of Agricultural Science. 92: 499-503.

Osuji, P.O., Nsahlai, I.V.. Khalili, H., 1993. Feed evaluation. ILCA Manual 5 ILCA ( international Livestock Centre for Africa), Addis Ababa, Ethiopia.40pp.

Overton, T. R., Cameron, M.R., Elliot, J.P., Clark, J.H., D.R. Nelson, D.R., 1995. Ruminal fermentation and passage of nutrients to the duodenum of lactating cows fed mixtures of corn and barley. Journal of Dairy Science 78:1981-1998

Preston, T.R., 1985. Strategies for Optimizing the Utilization of Crop Residues and Agro industrial Byproducts for Livestock Feeding in Tropics. Towards Optimal of Agricultural By-products to Livestock in Africa . Proceedings of a Workshop held at the University of Alexandria. International Livestock Center for Africa (ILCA), Egypt pp17.

Ramirez, R.G., 1991. Wood ash, sodium hydroxide and urine to increase sorghum straw utilization by sheep. Small Ruminant Research. 5: 83-92.

SAS, 2002. Statistical Analysis System. SAS user's guide: Statistics, SAS Inst. Inc., Carry, NC.

Solomon, A.K., Ulfina, G.G. and Gemeda, D.J., 2012. The potential of treatment with ash solution in improving degradability of fibrous feeds in Ethiopia. Agricultural Science Research Journal. 3: 100-105.

Steel, R.G.D. and Torrie, J.H., 1984. Principles and Procedures of Statistics. A Biometrical Approach ( $\left.2^{\text {nd }} E d\right)$. McGraw Hill Book Co. Inc. New York. USA. 
Sundstøl, F., 1985. Recent advances in development and utilization of chemically treated low quality roughages. In: (Eds. Wanapat, M., C. Devendra,). Relevance of Crop Residues as Animal Feeds in Developing Countries. Funny Press. Bangkok. Thailand. pp 121145.

Van Soest, P.J., Robertson, H.B. and Lewis, B.A. 1991. Methods of dietary fibre, NDF and non-starch polysaccharides in relation to animal material. Journal of Dairy Science. 74: 3583-3595.

Wanapat, M., Pilajun, R., Kangm, S., Satyaningsih, K. and Setyawan, A.R., 2012. Effect of ground maize cobs replacement for cassava chip on feed intake, rumen fermentation and urinary derivatives in swamp buffaloes. Asian-Australian Journal of Animal Science. 8: 1124-1131. 